\title{
Sources of Polycyclic Aromatic Hydrocarbons in an Environment Urbanised by Crude Oil Exploration
}

\author{
Inengite A. K. ${ }^{1}$, Oforka N. C. ${ }^{2} \&$ Osuji Leo C. ${ }^{2}$ \\ ${ }^{1}$ Department of Chemical Sciences, Niger Delta University, Bayelsa State, Nigeria \\ ${ }^{2}$ Department of Pure and Industrial Chemistry, University of Port Harcourt, Nigeria \\ Correspondence: Inengite A. K., Department of Chemical Sciences, Niger Delta University, Bayelsa State, \\ Nigeria. Tel: 234-803-341-8010. E-mail: ainengit@yahoo.com
}

Received: June 15, 2012 Accepted: July 14, 2012 Online Published: August 20, 2012

doi:10.5539/enrr.v2n3p62

URL: http://dx.doi.org/10.5539/enrr.v2n3p62

\begin{abstract}
Polycyclic Aromatic Hydrocarbons (PAHs) sources in Kolo Creek soil were predicted using Diagnostic Ratios (DRs) of parent PAHs [Phe/Phe+Ant; Fluo/Fluo+Pyr; BaA/BaA+Chry and Ind/Ind+BghiP]. The study was conducted in the dry and rainy seasons of 2008. The dry season had higher concentrations of PAHs than in the rainy season. Five ringed PAHs were dominant all through the study period. Applying cross plots of the DR values, revealed that in the rainy season, the PAHs were mainly of combustion origin, while in the dry season, it was a combination of petroleum and combustion sources, based on the activities domiciled in the sampling station during the period of study. Comparison of DR values obtained from this study with literature values enabled the further classification into combustion and/or petroleum sources. The combustion sources of PAHs were mainly as a result of Grass/Wood and petroleum combustion while the petroleum sources were as result of combined petroleum products. The predicted PAHs sources corresponded with the prevailing human activities in the vicinity, especially samples collected near a petrol station and an abattoir.
\end{abstract}

Keywords: PAHs, sources, diagnostic ratios, soil, Kolo Creek

\section{Introduction}

Generally, environmental pollution is ascribed to point sources, especially, in developing countries that have crude oil and gas as a natural resource. Oil and gas activities have been considered as major point source of related pollutants into the environment (Olajire et al., 2005; Agbozu et al., 2007), however, diffuse sources could also be major contributors.

Gas flaring has always been a culprit in these scenarios. Recently, in October 2011, a Nigerian village filed a law suit against Royal Dutch Shell Plc for polluting their drinking water and killing their crops, as a result of gas flaring (Cosgrove, 2011). Also, Nigerian Agip Oil Company was held responsible for having caused poor yields in farm produce due to gas flaring in a community in the Niger Delta.

It is a fact that gas flaring emits a number of hazardous products into the atmosphere which include but not limited to soot, toxic metals and Polycyclic Aromatic Hydrocarbons (PAHs). In order to defend themselves from litigations, most oil companies have been in the business of sponsoring technologies that can establish sources of pollution, for instance, fingerprinting of crude oil, which enables the establishment of facts as to which crude is responsible for which pollution.

These fingerprinting technologies, though not focused on gas flaring, Diagnostic Ratios (DRs) of PAHs provides a leeway for predicting PAHs sources. Yunker et al. (2002) carried out an assessment of PAHs sources and composition in the Fraser River Basin, establishing PAHs sources. Morillo et al. (2008) and Zhang et al. (2004) also determined PAH sources using diagnostic PAH ratios. Sixteen PAHs listed in the USEPA priority pollutants list were considered. They include: Naphthalene(Naph); Acenaphthene (Ace); Acenapthylene (Acen); Fluorene (Flu); Phenanthrene (Phe); Anthracene (Ant); Fluoranthene (Fluo); Pyrene (Pyr); 1,2-Benzanthracene (BaA); Chrysene (Chry); Benzo(b)fluorathene (Benzo(b)); Benzo(k)fluoranthene (Benzo(k)); Benzo(a) pyrene (BaP); 1,2,5,6-Dibenzanthracene (Diben); Indeno(1,2,3-C.D) pyrene (Ind); 1, 12-Benzopyrelene (BghiP).

When pollutants are released in gas flares, they eventually settle down as a result of dissolution in rainwater or bound to air-borne particles and soil eventually serves as sink. Ana et al. (2009); Aichner et al. (2007); Morillo et 
al. (2008) and Wang et al. (2010) have conducted several studies and have attributed atmospheric PAHs deposition as a major contributor to PAHs pollution in soil. In this study, PAHs found in soils around a flow station are used for their estimation and source prediction.

Due to the adverse health effects of PAHs (Zhang et al., 2004; Yunker et al., 2002; Ana et al., 2009) there is a desperate need to evaluate and determine their sources in the environment as to enable proper monitoring and control of emissions into the environment.

Various methods are being applied in PAHs source identification and apportionment. These include: emission inventory modelling approaches, multivariate statistical methods and the use of diagnostic ratios(DRs) of selected PAHs as reported by Dvorska et al. (2011); Wang et al. (1999); Sjogren et al. (1996); Westerholm and Li, (1994). Applying DRs for PAHs sources prediction holds advantages due to the ease of application (Dvorska et al, 2011; Morillo et al, 2008; Yunker et al, 2002; Wang et al, 2010) and unlike inventory modelling approaches, DRs do not rely on emissions inventories which may not be available in most countries especially developing countries.

The following PAHs DRs (Phe/Phe+Ant; Fluo/Fluo+Pyr; BaA/BaA+Chry and Ind/Ind+BghiP) were applied for source determination and apportionment of PAHs in Kolo Creek surface soils.

Kolo Creek is a region of Niger Delta that has been urbanised and industrialised due to the quest for crude oil and natural gas, a natural resource that is in abundance in the area and also a likely source of PAHs into the environment. As result of the exploitation and exploration of crude oil and natural gas, the ambient environment receives loads of human and industrial effluents which may be detrimental to the health of its inhabitants (Inengite et al., 2010a).

\section{Materials and Methods}

\subsection{Sampling Sites}

Seven sampling points $(\mathrm{Pt})$ were sampled, within $5 \mathrm{~km}$ radius around Kolo Creek flow station (Figure 1). Pt 1 was within the flow station, Pt 2 and Pt 3 were along a roadside in Otuasega, Pt 4 was around a palm-oil mill in Emeyal; Pt 5 was in an inhabited community (Imiringi), Pt 6 was close to a petrol station, while Pt 7 was in the vicinity of an abattoir at Tombia Junction.

The sampling field data are as shown in Table 1while Figure 1 is the map of the area studied.

Table 1. Sampling field data for soil

\begin{tabular}{cccc}
\hline Sampling Points & Station Location & Latitude(N) & Longitude(E) \\
\hline PT1 & Kolo Creek Flow Station & $4^{\circ} 53^{\prime} 10.920^{\prime \prime} \mathrm{N}$ & $6^{\circ} 22^{\prime} 12.727^{\prime \prime} \mathrm{E}$ \\
PT2 & Edepie-Imiringi road & $4^{\circ} 54^{\prime} 21.468^{\prime \prime} \mathrm{N}$ & $6^{\circ} 21^{\prime} 14.432 " \mathrm{E}$ \\
PT3 & Otuasega & $4^{\circ} 55^{\prime} 29.840^{\prime \prime} \mathrm{N}$ & $6^{\circ} 23^{\prime} 22.805^{\prime \prime} \mathrm{E}$ \\
PT4 & Emeyal II & $4^{\circ} 52^{\prime} 01.224^{\prime \prime} \mathrm{N}$ & $6^{\circ} 20^{\prime} 23.723^{\prime \prime} \mathrm{E}$ \\
PT5 & Imiringi & $4^{\circ} 51^{\prime} 29.750^{\prime \prime} \mathrm{N}$ & $6^{\circ} 22^{\prime} 37.932^{\prime \prime} \mathrm{E}$ \\
PT6 & Edepie Junction & $4^{\circ} 58^{\prime} 06.318^{\prime \prime} \mathrm{N}$ & $6^{\circ} 22^{\prime} 04.872 " \mathrm{E}$ \\
PT7 & Azikoro & $4^{\circ} 56^{\prime} 14.700^{\prime \prime} \mathrm{N}$ & $6^{\circ} 18^{\prime} 41.972 " \mathrm{E}$ \\
\hline
\end{tabular}

\subsection{Sampling}

Soil samples were collected using a stainless steel hand auger. Triplicate top soil $(0-15) \mathrm{cm}$ samples were collected at each point to form one composite sample forming a total of 28 composite soil samples for the dry and rainy seasons (Table1). The samples were wrapped in aluminium foil stored in an ice chest and taken to the laboratory and stored at $-20^{\circ} \mathrm{C}$ prior to analysis.

\subsection{Extraction PAHs from Soil Samples}

The samples were dried, crushed and sieved using $0.5 \mathrm{~mm}$ sieve. $2.0 \mathrm{~g} \pm 0.01$ of samples were weighed and spiked with pre-deuterated PAHs mixture (naphthalene- $\mathrm{d}_{8}$, phenanthrene- $\mathrm{d}_{10}$, chrysene- $\mathrm{d}_{12}$, and perylene- $\mathrm{d}_{12}$ ) as an internal standard, to determine the extraction efficiency. The recovery was $>90 \%$. $10 \mathrm{ml}$ of extraction solvent (pentane) was added into the samples and mixed thoroughly and allowed to settle. The mixtures were carefully 
filtered into clean solvent rinsed extraction bottles using filter paper fitted into Buchner funnels. The extracts were concentrated to $2 \mathrm{ml}$ and then transferred for clean up/separation.

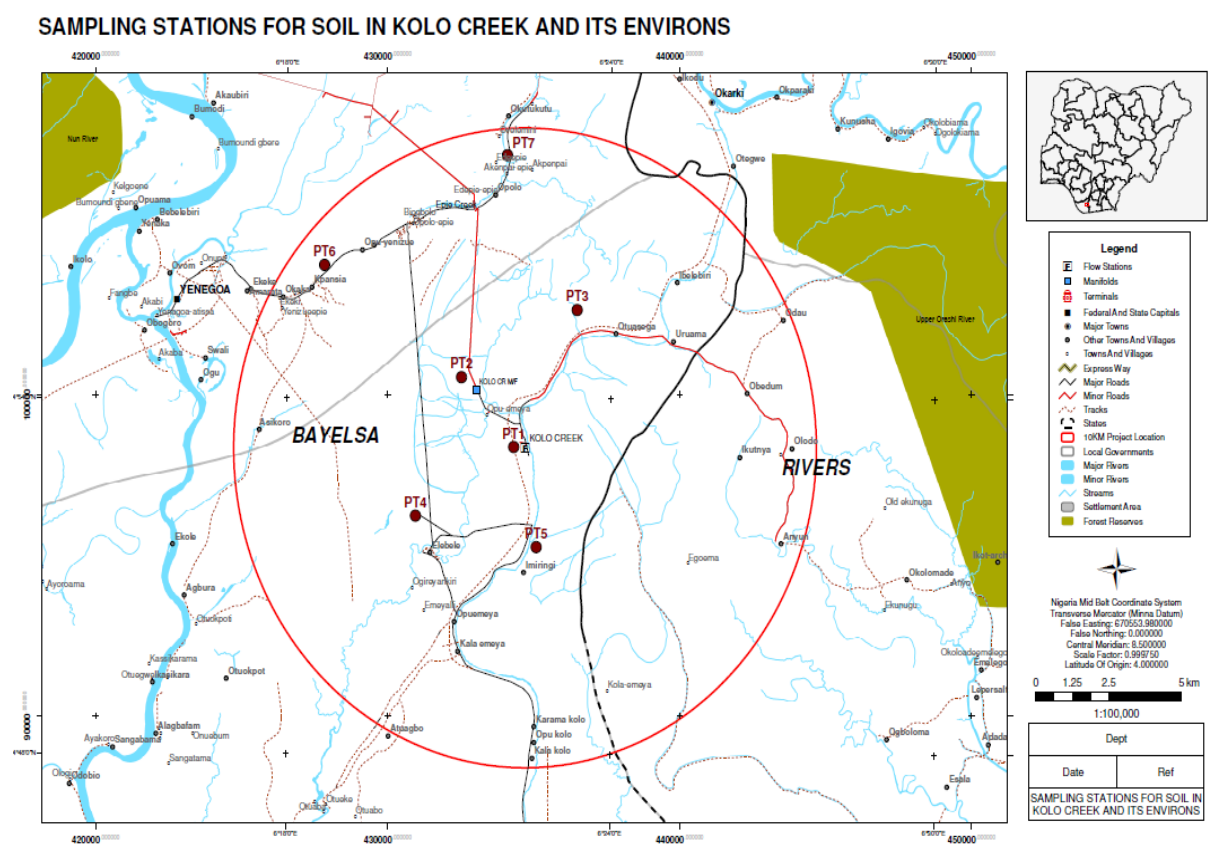

Figure 1. Map showing sampling stations

\subsection{Sample Clean-up}

In a $10 \mathrm{~mm}$ id x $250 \mathrm{~mm}$ long chromatographic column, $1 \mathrm{~cm}$ of moderately packed glass wool was placed at the bottom. Slurry of $2 \mathrm{~g}$ activated silica gel in $10 \mathrm{ml}$ of Dichloromethane (DCM) was prepared and placed into the chromatographic column. To the top of the column was added $0.5 \mathrm{~cm}$ of sodium sulphate. The column was rinsed with additional $10 \mathrm{ml}$ of DCM. The column was pre-eluted with $20 \mathrm{ml}$ of Pentane; this was allowed to flow through the column for about 2 minutes until the liquid in the column was just above the sulphate layer. Immediately, $1 \mathrm{ml}$ of the extracted sample was transferred into the column, the extraction bottle was rinsed with $1 \mathrm{ml}$ of Pentane and added to the column as well. The stop-cock of the column was opened and the eluent was collected with a $10 \mathrm{ml}$ graduated cylinder. Just prior to exposure of the sodium sulphate layer to air, Pentane was added to the column in 1-2ml increments. Accurately measured volume of $8-10 \mathrm{ml}$ of the eluent was collected. This was labelled "aliphatic". Following recovery of the "aliphatic" fractions just prior to exposure of the sodium sulphate layer, the column was eluted with 1:1 mixture of propanone and DCM in 1-2ml increments. Another accurately measured $8-10 \mathrm{ml}$ of the eluent was collected and was labelled "aromatics". The "aromatics" fraction was concentrated to $1 \mathrm{ml}$ for PAHs analysis using Gas Chromatography.

\subsection{Gas Chromatographic (GC) Analysis}

The concentrated "aromatics" fractions were transferred into labelled Glass Vials with Teflon Rubber Crimp caps for GC analysis. $1 \mu 1$ of the concentrated sample was injected by means of hypodermic syringe through a rubber septum into the column. Separation occurs as the vapour constituent partition between the gas and liquid phases. The sample was automatically detected as it emerges from the column by a Flame Ionization Detector (FID). The Operational Conditions for GC Analysis are as stated in Inengite et al. (2010b).

\section{Results and Discussion}

The results of the PAHs concentrations in the soils are as stated in Table 2. The PAHs Diagnostic Ratios for the various periods of the year that the study was conducted are as stated in Table 3 . Half the values of the detection limit of the gas chromatograph were used to represent values below the detection limit of the gas chromatograph, to take care of missing values. 
Table 2. PAHs concentrations in Kolo Creek soil (mg/Kg)

\begin{tabular}{|c|c|c|c|c|c|c|c|c|c|c|c|c|c|c|c|c|}
\hline \multicolumn{3}{|c|}{$\begin{array}{l}\text { SamplingSeasonsNaph } \\
\text { Stations }\end{array}$} & Ace & Acen 1 & Flu & Phe & & Fluo & Pyr & $\mathrm{BaA}$ & $\mathrm{Chr}$ & \multicolumn{4}{|c|}{ Benzo(b)Benzo(K)Benzo(a)Ind } & $\begin{array}{r}\text { Diben BghiP Total MeanStd. } \\
\text { Dev. }\end{array}$ \\
\hline \multirow[t]{2}{*}{ PT1 } & $\mathrm{D}$ & 0.005 & 50.008 & 0.011 & 0.002 & $2<0.001$ & 10.001 & 0.002 & $20.010<$ & $<0.001$ & 10.008 & 0.007 & 0.009 & 0.013 & 0.004 & $0.003<0.0010 .0820 .0060 .00$ \\
\hline & $\mathrm{R}$ & & $1<0.001<$ & $<0.001$ & 0.001 & $1<0.001$ & $1<0.001<$ & $<0.001<$ & $1<0.001$ & 0.002 & 20.002 & & & 0.038 & 0.008 & $\begin{array}{lll}8 & 0.011 & 0.0020 .0780 .0080 .0\end{array}$ \\
\hline \multirow[t]{2}{*}{ PT2 } & $\mathrm{D}$ & .001 & 0.010 & 0.012 & 0.003 & $3<0.001<$ & $1<0.001<$ & $<0.001$ & $10.004<$ & $<0.001$ & 10.006 & & 0.004 & 0.002 & 0.007 & $7 \quad 0.007<0.0010 .0640 .0060 .0$ \\
\hline & $\mathrm{R}$ & 0.001 & $<0.001<$ & $<0.001<$ & $<0.001<$ & $<0.001<$ & $1<0.001<$ & $<0.001<$ & $1<0.001$ & 0.001 & 10.001 & & 0.002 & 0.002 & 0.002 & $20.003<0.0010 .01$ \\
\hline \multirow[t]{2}{*}{ T3 } & $\mathrm{D}$ & & 0.011 & 0.013 & 0.002 & $2<0.001<$ & $1<0.001<$ & $<0.001$ & $10.005<$ & $<0.001$ & 10.007 & & & 0.002 & 0.007 & $7 \quad 0.007<0.0010 .0670 .0070 .0$ \\
\hline & $\mathrm{R}$ & & $<0.001<$ & $<0.001<$ & $<0.001<$ & & $1<0.001<$ & $<0.001<$ & $1<0.001<$ & $<0.001$ & 10.004 & & & $0,003<$ & $<0.001$ & $0.004<0.0010 .01$ \\
\hline \multirow[t]{2}{*}{ T4 } & $\mathrm{D}$ & & 0.013 & 0.016 & 0.003 & & $10.002<$ & $<0.001$ & $10.005<$ & $<0.001$ & 10.004 & & & $0002<$ & $<0.001$ & $1 \quad 0.000<0.0010 .0520 .00$ \\
\hline & $\mathrm{R}$ & & $<0.001<$ & $<0.001<$ & $<0.001<$ & $\mid<0.001<$ & $1<0.001<$ & $<0.001<$ & $1<0.001<$ & $<0.001<$ & $1<0.001$ & 0.003 & $<0.001$ & $<0.001$ & 0.003 & $30.004<0.0010 .0090 .0030 .0$ \\
\hline \multirow[t]{2}{*}{ Р5 } & $\mathrm{D}$ & & 0.007 & 0.020 & 0.019 & 0.007 & $7 \quad 0.039$ & 0.006 & 60.003 & 0.021 & 10.026 & & & 0.055 & 0.003 & $30.005<0.00$ \\
\hline & $\mathrm{R}$ & $<0.001$ & $<0.001<$ & $<0.001<$ & $<0.001<$ & $<0.001<$ & $1<0.001<$ & $<0.001<$ & $1<0.001$ & 0.005 & 50.002 & & & $0.005<$ & $<001<$ & \\
\hline \multirow[t]{2}{*}{ PT6 } & $\mathrm{D}$ & & 0.013 & 0.005 & 0.005 & 50.027 & 70.012 & 0.039 & 90.011 & 0.015 & & & & 0.002 & $0.003<$ & $3<0.001 \quad 0.014$ \\
\hline & $\mathrm{R}$ & & & $<0.001<$ & $<0.001<$ & $\mid<0.001<$ & $1<0.001<$ & $<0.001<$ & $1<0.001<$ & $<0.001$ & 10.002 & & 0.009 & $0.007<$ & 500018 & $1<0.001 \quad 0.0100 .0400 .0080 .00$ \\
\hline \multirow[t]{2}{*}{ PT7 } & $\mathrm{D}$ & $<0.001$ & 0.003 & 0.002 & 0.006 & $<0.001<$ & $1<0.001$ & 0.010 & 0.008 & 0.002 & 0.007 & & & 0.003 & 0.003 & $0.007<0.0010 .0590 .0050 .00$ \\
\hline & $\mathrm{R}$ & $<0.001$ & $<0.001<$ & $<0.001<$ & $<0.001<$ & $<0.001<$ & $1<0.001<$ & $<0.001<$ & $1<0.001$ & 0.003 & 0.004 & & & 0.002 & 0.006 & $5 \quad 0.003<0.0010 .0220 .0030 .00$ \\
\hline \multicolumn{2}{|l|}{ Mean } & & 0.009 & 0.011 & 0.005 & 0.017 & & 0.014 & 40.006 & 0.007 & & & 0.012 & 0.011 & 0.005 & $50.005 \quad 0.0090 .0780 .0070 .00$ \\
\hline \multicolumn{2}{|c|}{ Std. Dev. } & 0.006 & 0.004 & 0.006 & 0.006 & 0.014 & 0.017 & 0.017 & 70.003 & 0.008 & 0.008 & 0.010 & 0.024 & 0.017 & 0.002 & $\begin{array}{lll}2 & 0.003 & 0.0060 .0880 .0050 .00\end{array}$ \\
\hline
\end{tabular}

D(Dry Season) (November-March); R(Rainy Season)(April-October) Naph-Naphthalene; Ace- Acenaphthene; Acen- Acenapthylene; Flu- Fluorene; Phe-Phenanthrene; Ant-Anthracene; Fluo-Fluoranthene; Pyr-Pyrene; BaA-1,2-Benzanthracene; Chry-Chrysene; Benzo(b)- Benzo(b)fluorathene; Benzo(k)- Benzo(k)fluoranthene; BaP- Benzo(a) pyrene; Diben-1,2,5,6-Dibenzanthracene; Ind- Indeno(1,2,3-C.D) pyrene; BghiP-1, 12-Benzopyrelene

Table 3. PAHs ratios for source and composition determination in Kolo Creek soil

\begin{tabular}{lcccccccc}
\hline Stations & \multicolumn{2}{c}{ Ant/Ant + Phe } & \multicolumn{2}{c}{ Fluo/Fluo + Pyr } & \multicolumn{2}{c}{ BaA/BaA + Chry } & \multicolumn{2}{c}{ Ind/Ind + BghiP } \\
\hline & $\mathrm{D}$ & $\mathrm{R}$ & $\mathrm{D}$ & $\mathrm{R}$ & $\mathrm{D}$ & $\mathrm{R}$ & $\mathrm{D}$ & $\mathrm{R}$ \\
PT1 & 0.72 & 0.50 & 0.15 & 0.50 & 0.06 & 0.48 & 0.86 & 0.84 \\
PT2 & 0.50 & 0.50 & 0.11 & 0.50 & 0.07 & 0.43 & 0.93 & 0.87 \\
PT3 & 0.50 & 0.50 & 0.10 & 0.50 & 0.07 & 0.12 & 0.93 & 0.88 \\
PT4 & 0.79 & 0.50 & 0.09 & 0.50 & 0.11 & 0.50 & 0.00 & 0.89 \\
PT5 & 0.84 & 0.50 & 0.65 & 0.50 & 0.45 & 0.73 & 0.91 & 0.50 \\
PT6 & 0.31 & 0.50 & 0.78 & 0.50 & 0.40 & 0.20 & 0.00 & 0.05 \\
PT7 & 0.50 & 0.50 & 0.56 & 0.50 & 0.21 & 0.44 & 0.93 & 0.85 \\
Mean & 0.60 & 0.50 & 0.35 & 0.50 & 0.20 & 0.41 & 0.65 & 0.70 \\
Std. Dev. & 0.19 & 0.00 & 0.30 & 0.00 & 0.16 & 0.20 & 0.45 & 0.32 \\
\hline
\end{tabular}

The mean levels of PAHs in Kolo Creek soil at the time of study was $(7.0 \pm 5.0) \times 10^{-3} \mathrm{mg} / \mathrm{Kg}$. This value is below the critical value of $4.0 \mathrm{mg} / \mathrm{Kg}$ for total PAHs in soil (ANZECC, 2000). According to Maliszewska-Kordybach (1996), Kolo Creek soil is classified as not contaminated during the period that the study was conducted.

The individual PAHs were in the order: $\operatorname{Phe}(0.017)>\operatorname{Fluo}(0.014)>\operatorname{Ant}(0.013)>\operatorname{Benzo}(\mathrm{k})(0.012)>$ Benzo(a) $(0.011)=$ Acen $>\operatorname{BghiP}(0.009)=$ Ace $>\operatorname{Benzo}(b)(0.008)>\operatorname{Naph}(0.007)=\operatorname{BaA}=\operatorname{Chry}>\operatorname{Pry}(0.006)>$ $\operatorname{Flu}(0.005)=$ Ind $=$ Diben. 
The dry season had higher concentrations of total PAHs than the rainy season in all the sampling points that the study was conducted.

Five ringed PAHs were persistent all through the period of study, Ind which is a six ringed PAH was also persistent, however, BghiP was hardly detected except at Pt 6 where high concentrations of 0.014 and 0.010 $\mathrm{mg} / \mathrm{Kg}$ were recorded in the dry and rainy seasons respectively. This could be attributed to the microbial production of BghiP as a result of microbial activities in the abattoir area (Venkatesan, 1988), since the sampling point is in the vicinity of an abattoir.

The most persistent 4-ringed is Chry. It was more persistent than the other 4-ringed PAHs.

The order of persistence was as shown in Figure 2.<smiles>c1ccc2c(c1)ccc1ccccc12</smiles>

Chyr<smiles>c1cc2ccc3cccc4ccc(c1)c2c34</smiles>

Pyr<smiles>c1ccc2cc3ccccc3cc2c1</smiles>

$\mathrm{BaA}$<smiles>c1ccc2c(c1)-c1cccc3cccc-2c13</smiles>

Fluo

Figure 2. The order of persistence

2 and 3 ringed PAHs were relatively found more in the dry season.

Phe, which had the highest concentration of all the PAHs studied was observed only in Pt5 (0.007) and Pt6 (0.027), in the dry season. Occurring only in two stations, and dominating in concentration, it is likely to have been introduced into the environment from major point sources. It noteworthy, that Pt5 is situated around a local palm-oil mill, while Pt 6 is in the vicinity of an abattoir and a petrol station.

In general, PAHs in soil were greater in the dry season than in the rainy season. During the rainy season, it is expected that dissolution and washing-off of the PAHs from the soil matrix could occur (Karlsson \& Viklander, 2008; Morillo et al., 2008).

\section{PAH-CROSS-PLOTS·FOR-VARIOUS-PAH·RATIOS-IN-SOIL-IN-THE-DRY-SEASON.}

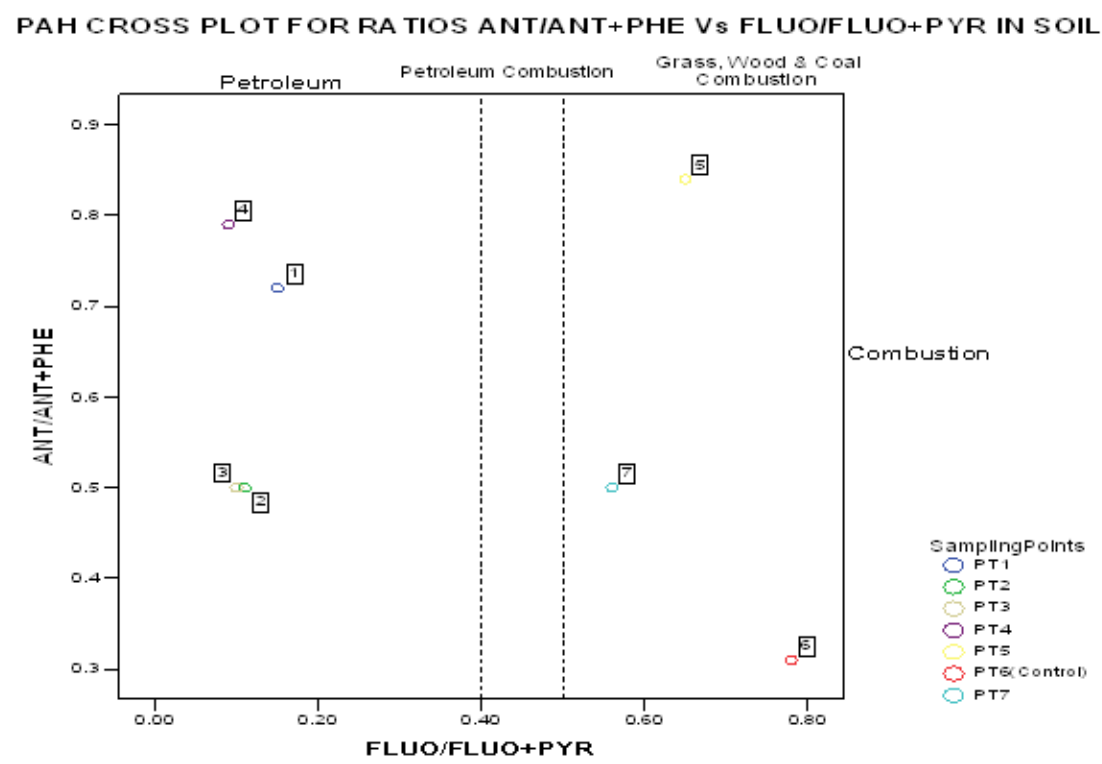

Figure 3. PAHs cross plots ratios Ant/Ant+Phe Vs Fluo/Fluo+Pyr in soil of Kolo Creek in the dry season 
PAH CROSS PLOTS FOR BENZIBENZ+CHR Vs FLUOIFLUO+PYR IN SOIL

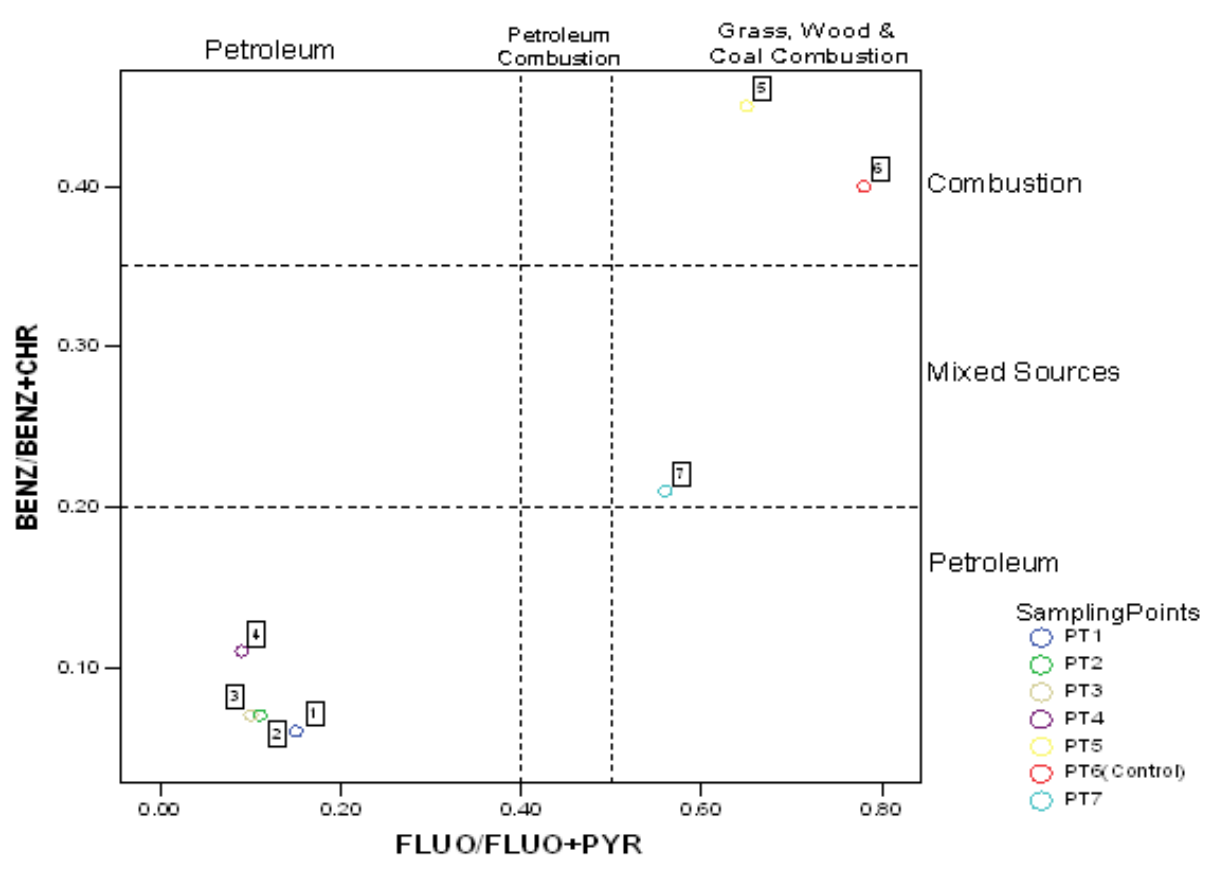

Figure 4. PAHs cross plots ratios $\mathrm{BaA} / \mathrm{BaA}+\mathrm{Chr}$ Vs Fluo/Fluo+Pyr in soil of Kolo Creek in the dry season

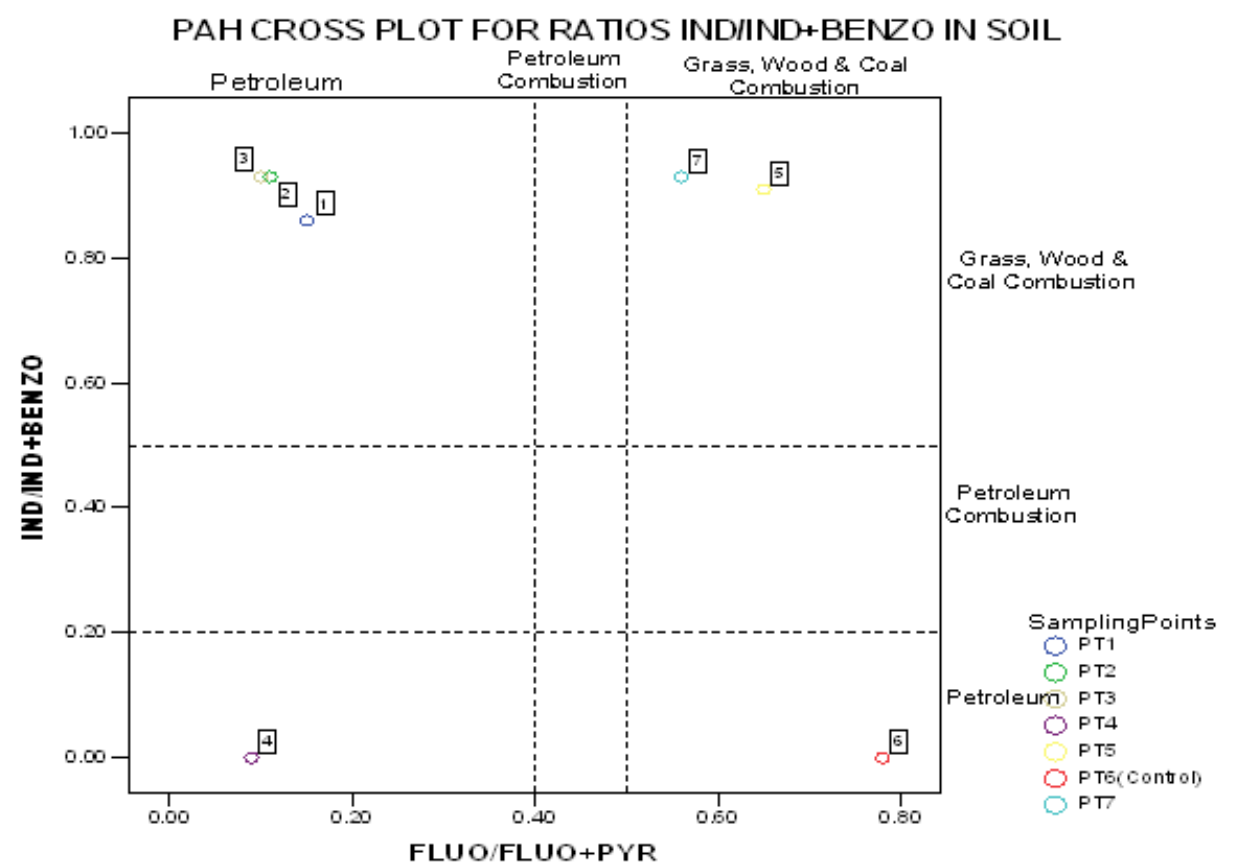

Figure 5. PAHs cross plots ratios Ind/Ind+BghiP Vs Fluo/Fluo+Pyr in soil of Kolo Creek in the dry season

The highest concentrations of PAHs were recorded for BaA in Pt5 (0.021) and Pt6 (0.015), these points had about twice and more the concentrations of PAHs than in the other points.

PAHs sources have been predicated using diagnostic ratios conventionally and reported in literature (Yunker et al., 2002; Morillo et al., 2008; Olajire \& Brack, 2005). These ratios include but not limited to Ant/Ant + Phe; Fluo/Fluo + Pyr; BaA/BaA+Chry And Ind/Ind+Bghip. The Ant/Ant + Phe ratio presumes that ratios $<0.1$ indicate PAHs source to be of petroleum origin while ratios $>0.1$ indicate PAHs source to be of combustion origin 
(Budzinski et al., 1997). The Fluo/Fluo+Pyr ratio presumes that ratios in the range $\geq 0.4$ and $\leq 0.5$ indicate petroleum combustion, ratios $<0.4$ indicate petroleum sources while ratios $>0.5$ indicate grass, wood and coal combustion. $\mathrm{BaA} / \mathrm{BaA}+$ Chry presumes that ratios $<0.2$ are of petroleum origin, ratios in the range $\geq 0.2$ and $\leq 0.35$ as mixed sources and $>0.35$ as combustion sources. Lastly, Ind/Ind+BghiP presumes that PAHs ratios $<0.2$ indicate petroleum sources, ratios in the range $\geq 0.2$ and $\leq 0.5$ as petroleum combustion sources and $>0.5$ as grass, wood and coal combustion sources (Inengite et al., 2010b; Yunker et al., 2002; Budzinski et al., 1997; Morillo et al., 2008; Olajire et al., 2005). Cross plots of these ratios and their cut-off values for the various predicted sources are explicitly elaborated in Figures 3 to 6 for the four periods of the year that the study was conducted.

The PAH cross plots in Figures 3-6 illustrates the distribution of the sampling points into predicted sources for the dry and rainy seasons. Figures 3-5 represents the crossplots for the four PAHs ratios in the dry season, while Figure 6 represents crossplot of $\mathrm{BaA} / \mathrm{BaA}+$ Chry Vs Ind/Ind + BghiP, in the rainy season.

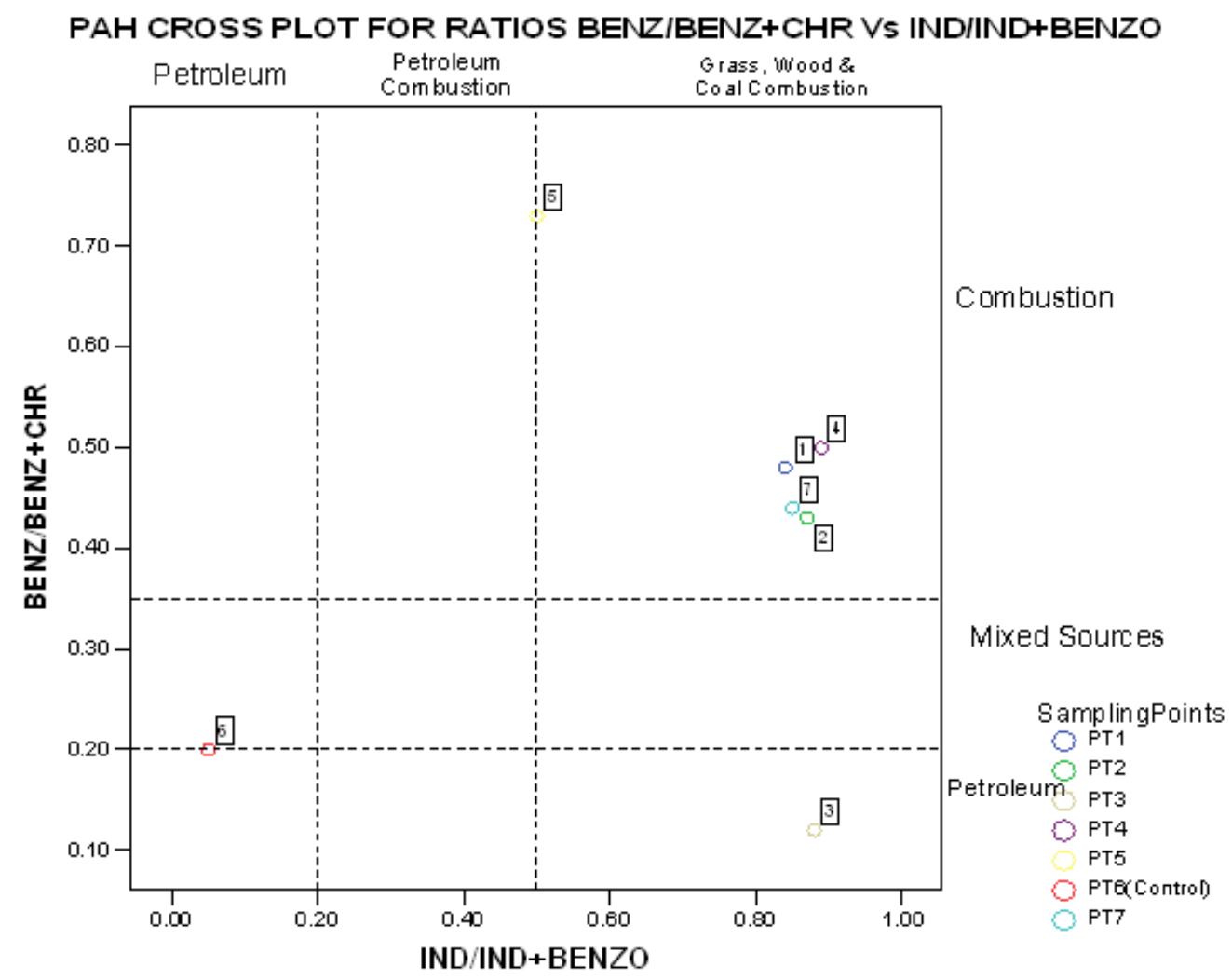

Figure 6. PAHs cross plots ratios $\mathrm{BaA} / \mathrm{BaA}+\mathrm{Chr} \mathrm{Vs}$ Ind/Ind+BghiP in soil of Kolo Creek in the rainy season

The sampling points were clustered based on similarities of PAHs sources. In Figure 3, two major clusters were observed, cluster of Petroleum sources which contained sampling points 1, 2, 3 and 4 and cluster of grass/wood and coal combustion which contained sampling points 5,6 and 7 .

In Figure 4, three clusters were observed, cluster of petroleum sources containing sampling points 1, 2, 3 and 4, cluster of grass/ wood and coal combustion which contained sampling 5 and 6. Sampling point 7 was contained in the cluster of mixed PAHs sources.

Finally for the dry season, Figure 5 shows three clusters. Cluster of Petroleum/ Grass, wood and coal combustion sources containing sampling points 1,2,3 and 6; cluster of petroleum sources containing sampling point 4 and cluster of grass, wood and coal combustion sources containing sampling points 5 and 7 .

In the rainy season, Figure 6 illustrates three clusters. Cluster of combustion/ grass, wood and coal combustion sources containing sampling points 1,2, 4, 5 and 7; cluster of petroleum sources containing sampling point 6 and cluster of petroleum/ grass, wood and coal combustion sources containing sampling point 3 .

The general observation from the PAH cross plots in the dry season, indicates that sampling points 1-4 had major 
contribution of PAHs from petroleum sources, while sampling points 5, 6 and 7 were mainly of combustion origins.

In the rainy season, sampling point 6 was outstandingly of petroleum origin, while the rest sampling points were of combustion origin.

These PAH ratios corresponded with previous studies where PAHs ratios were determined empirically for specific substances.

Freeman and Cattal (1990) determined PAHs ratios for bush fires and stated empirical data. Fine et al. (2001) also determined PAH ratios for wood combustion, giving the ind/ind + BghiP ratio to be $0.64 \pm 0.07$ (0.49-0.77). Grimmer et al. (1983) gave empirical PAH ratio (Fluo/Fluo+Pyr) for crude oil to be $0.22 \pm 0.07(0.14-0.26)$.

\section{Conclusion}

The major anthropogenic sources of PAHs in the soil of Kolo Creek were of pyrogenic origin. There were, however, petrogenic sources that were close to point sources as in the case of the sampling point that is in the proximity of a petrol station and also in the rainy season that petroleum products were allegedly washed and drained away by storm water. The pyrogenic sources were a combination of Grass/Wood Combustion and petroleum Combustion. These predictions correspond with the types of activities within the vicinity of the sampling stations in question. Though, in the vicinity of a gas flare, the findings in this study show that diffuse sources also play an important role in environmental pollution.

\section{Acknowledgement}

The authors are grateful to Niger Delta University and the Shell Petroleum Development Company of Nigeria Limited for their support.

\section{References}

Agbozu, I. E., Ekweozor, I. K. E., \& Opuene, K., (2007). Survey of heavy metals in the catfish Synodontis claria. Int. J. Environ. Sci. Tech., 4(1), 93-97.

Aichner, B., Glaser, B., \& Zech, W. (2007). Polycyclic Aromatic Hydrocarbons and Polychlorinated Biphenyls in Urban Soils from Kathmandu, Nepal. Organic Geochemistry, 38(4), 700-715. http://dx.doi.org:10.1016/j.orggeochem.2006.11.002

Ana, G. R. E. E., Sridhar, M. K. C., \& Emerole, G. O. (2009). A comparative assessment of soil pollution by polycyclic aromatic hydrocarbons in two Niger Delta communities, Nigeria. African Journal of Pure and Applied Chemistry, 3(3), 31-41.

ANZECC. (2000). Australian and New Zealand guidelines for fresh and marine water quality. Australian and New Zealand Environment and Conservation Council.

Budzinski, H., Jones, I., Bellocq, J., Pie'rard, C., \& Garrigues, P., (1997). Evaluation of sediment contamination by polycyclic aromatic hydrocarbons in the Gironde estuary. Mar. Chem., 58(1-2), 85-97. http://dx.doi: 10.1016/S0304-4203(97)00028-5

Dvorska, A., Lammel, G., \& Klanova, J. (2011). Use of diagnostic ratios for studying source apportionment and reactivity of ambient polycyclic aromatic hydrocarbons over Central Europe. Atmos. Environ., 45(2), 420-427. http://dx.doi: 10.1016/j.atmosenv.2010.09.063

Fine, P. M., Cass, G. R., \& Simoneit, B. R. (2001). Chemical characterization of fine particle emissions from fireplace combustion of woods grown in the northeastern United States. Environ. Sci. Technol., 35(13), 2665-2675. http://dx.doi: 10.1021/es001466k

Freeman, D. J., \& Cattell, F. C. (1990). Woodburning as a source of atmospheric polycyclic aromatic hydrocarbons. Environ. Sci. Technol., 24, 1581-1585. http://dx.doi.org/10.1021/es00080a019

Grimmer, G., Jacob, J., \& Naujack, K.-W. (1983). Profile of the polycyclic aromatic compounds from crude oils. Part 3. Inventory by GCGC/MS-PAH in environmental materials. Fresenius Z. Anal. Chem., 314, 29-36. http://dx.doi.org/10.1007/BF00476507

Inengite, A. K., Oforka, N. C., \& Osuji, L. C. (2010a). Survey of heavy metals in sediments of Kolo creek in the Niger Delta, Nigeria. African Journal of Environmental Science and Technology, 4(9), 558-566.

Inengite, A. K., Oforka, N. C., \& Osuji, L. C. (2010b). Evaluation of Polycyclic Aromatic Hydrocarbons in Sediment of Kolo Creek in the Niger Delta. International Journal of Applied Environmental Science, 5(1) 127-143. 
Karlsson, K., \& Viklander, M. (2008). Polycyclic Aromatic Hydrocarbons(PAH) in Water and Sediment from Gully Pots. Water Air Soil Pollution, 188(1-4), 271-282. http://dx.doi:10.1007/s11270-007-9543-5

Maliszewska-Kordybach, B. (1996). Polycyclic aromatic hydrocarbons in agricultural soils in Poland: Preliminary proposals for criteria to evaluate the level of soil contamination. Applied Geochemistry, 11(1-2), 121-127. http://dx.doi:10.1016/0883-2927(95)00076-3

Morillo, E., Romero, A., S., Madrid, L., Villaverde, J., \& Maqueda, C. (2008). Characterization and Sources of PAHs and Potentially Toxic Metals in Urban Environments of Sevilla (Southern Spain). Water Air Soil Pollution, 187(1-4), 41-51. http://dx.doi: 10.1007/s11270-007-9495-9

Olajire, A. A., \& Brack, W. (2005). Polycyclic Aromatic Hydrocarbons in Niger Delta Soil: Contamination Sources and Profiles. Int. J of Environ Sci. Tech., 2(7), 343-352.

Olajire, A., A., Altenburger, R., Kuster, E., \& Brack, W. (2005). Chemical and Ecotoxological Assessment of Polycyclic Aromatic Hydrocarbon-Contaminated Sediments of the Niger Delta, Southern Nigeria. Sci Total Environ., 340(1-3), 123-136. http://dx.doi:10.1016/j.scitotenv.2004.08.014

Sjogren, M., Li, H., Rannug, U., \& Westerholm, R. (1996). Multivariate analysis of exhaust emissions from heavy-duty diesel fuels. Environ. Sci. Technol., 30(1), 38-49. http://dx.doi:10.1021/es940772t

Venkatesan, M. (1988). Occurrence and possible sources of perylene in marine sediments-a review. Marine Chemistry, 25, 1-27. http://dx.doi.org/10.1016/0304-4203(88)90011-4

Wang, X. U., Li, Q. B., Luo, Y. M., Ding, Q., Xi, L. M., Ma, J. M., ... Cheng, C. L. (2010). Characteristics and Sources of Atmospheric Polycyclic Aromatic Hydrocarbons (PAHs) in Shanghai, China. Environ Monit Assess., 165, 295-305. http://dx.doi:10.1007/s10661-009-0946-1

Wang, Z., Fingas, M., Shu, Y. Y., Sigouin, L., Landriault, M., Lambert, P., ... Mullin, J. (1999). Quantitative characterization of PAHs in burn residue and soot samples and differentiation of pyrogenic PAHs from petrogenic PAHs - the 1994 Mobile burn study. Environ. Sci. Technol, 33(18), 3100-3109. http://dx.doi: 10.1021/es990031y

Westerholm, R. N., \& Li, H. (1994). A multivariate statistical analysis of fuel-related polycyclic aromatic hydrocarbon emissions from heavy-duty diesel vehicles. Environ. Sci. Technol, 28(5), 965-972. http://dx.doi: $10.1021 / \mathrm{es} 00054 \mathrm{a} 032$

Yunker, M. B., Macdonald, R. W., Vingarzan, R., Mitchell, H., Goyette, D., \& Sylvestre, S. (2002). PAHs in the Fraser River basin: a critical appraisal of PAHs ratios as indicators of PAH source and composition. Organic Geochemistry, 33(4), 489-515. http://dx.doi:10.1016/S0146-6380(02)00002-5

Zhang, Z., Huang, J., Yu, G., \& Hong, H. (2004). Occurrence of PAHs, PCBs and Organochlorine Pesticides in the Tonghui River of Beijing, China. Environmental Pollution, 130(2), 249-261. http://dx.doi:10.1016/j.envpol.2003.12.002 